\title{
A trial of zinc supplementation in young rural Gambian children
}

\author{
BY C. J. BATES, ${ }^{1}$ P. H. EVANS, ${ }^{1}$ M. DARDENNE, ${ }^{2}$ A. PRENTICE, ${ }^{1}$ P. G. LUN N, ${ }^{1}$ \\ C. A. NORTHROP-CLEWES, ${ }^{1}$ S. HOARE, ${ }^{1}$ T. J. COLE, ${ }^{1}$ S. J. HORAN, ${ }^{1}$ \\ S. C. LONGMAN, ${ }^{1}$ D. STIRLING ${ }^{1}$ AND P. J. AGGETT ${ }^{3}$ \\ ${ }^{1}$ MRC Dunn Nutrition Unit, Milton Road, Cambridge CB4 IXJ and Keneba, The Gambia, \\ W. Africa \\ ${ }^{2}$ Immunologie Clinique, Hôpital Necker, 161 Rue de Sèvres, 75743 Paris, Cedex 15, France \\ ${ }^{3}$ AFRC Institute of Food Research, Norwich Laboratory, Colney Lane, Norwich NR4 7UA
}

(Received 20 August 1991 - Accepted 28 January 1992)

\begin{abstract}
The present study tested the hypothesis that inadequate $\mathrm{Zn}$ intake might be responsible for failure to thrive and impaired catch-up growth in young rural Gambian children, and that $\mathrm{Zn}$ supplements might be beneficial. Gambian children might be deprived of $\mathrm{Zn}$ because of its poor availability from their predominantly plant-based diet. Rural Gambian children (110; fifty boys, sixty girls) aged between 0.57 and 2.30 years were divided into two matched groups, one to receive $70 \mathrm{mg} \mathrm{Zn}$ twice weekly for 1.25 years, and the other a placebo. Growth and mid-upper-arm circumference were measured at weekly intervals throughout the study and illnesses were monitored. Capillary blood and urine samples were collected at 0, 2 and 8 weeks. Body weights and arm circumferences showed a linear increase, plus a seasonal effect (rainy season faltering). For body weight there was no significant overall effect of the supplement. For arm circumference, a very small $(2 \%)$ but significant $(P<0.01)$ difference favoured the supplemented group. Plasma thymulin was much lower at the first clinic than at the second and third clinics, and in vitro $\mathrm{Zn}$ stimulation was greater at the first clinic. There was, however, no effect of $\mathrm{Zn}$ in vivo. Likewise, $\mathrm{Zn}$ did not significantly benefit $\mathrm{T}$-cell numbers or ratios, secretory IgA in urine, circulating hormone levels or biochemical indices of $\mathrm{Zn}$ status. One index of intestinal permeability, i.e. lactulose: creatinine, was improved $(P<0.02)$ by the supplement, but the lactulose: mannitol value was not; this requires further investigation. Dietary $\mathrm{Zn}$ deficiency is, thus, unlikely to be of major overall importance for rural Gambian children's ability to thrive, and blanket $\mathrm{Zn}$ supplementation is not justified. There may, however, be vulnerable sub-groups who would benefit from $\mathrm{Zn}$ supplements.
\end{abstract}

Zinc: Infants: Supplementation: Growth: Thymulin

Young Gambian children in rural farming communities grow, on average, at a rate consistent with international standards for the first 3 months of life while exclusively breastfed, but during weaning, when the locally-available foods are of poor nutritional quality and are highly contaminated with pathogens, they fail to thrive, fail to catch up adequately after growth-faltering, and decline from international growth norms (Rowland et al. 1977).

There are many reasons for this decline. One, which would be relatively easily and cheaply correctable if important, is dietary $\mathrm{Zn}$ deficiency. $\mathrm{Zn}$ availability may be poor in the diets of weanling infants of developing countries, since there is universal dependency on cereal staples but little animal protein or other easily utilized sources of $\mathrm{Zn}$ (Ferguson et al. 1989). A recent study of rural Gambian adolescents (Watkinson et al. 1985) showed that plasma $\mathrm{Zn}$ was below Western reference ranges. Unfortunately there are no reliable biochemical indices of marginal $\mathrm{Zn}$ status, particularly for young children; it is therefore, essential to use controlled supplementation, assessed by anthropometric indices (Walravens 
Table 1. Characteristics of young rural Gambian children allocated to placebo and zincsupplemented groups

(Mean values with their standard errors)

\begin{tabular}{|c|c|c|c|c|c|c|c|c|}
\hline & \multicolumn{4}{|c|}{ Unsupplemented group } & \multicolumn{4}{|c|}{ Zn-supplemented group } \\
\hline & $n$ & Mean & SE & Range & $n$ & Mean & $\mathbf{S E}$ & Range \\
\hline \multicolumn{9}{|l|}{ Age (years) at outset } \\
\hline Keneba* & 20 & 1.65 & 0.058 & $1 \cdot 22-2 \cdot 04$ & 19 & 1.68 & 0.053 & $1 \cdot 30-2 \cdot 06$ \\
\hline Manduar and Kanton Kundar* & 34 & $1 \cdot 39$ & 0.078 & $0.57-2 \cdot 30$ & 36 & 1.35 & 0.065 & $0 \cdot 67-2 \cdot 22$ \\
\hline Percentage of males (all three villages) & & $46 \cdot 3$ & & & & $43 \cdot 6$ & & \\
\hline \multicolumn{9}{|l|}{ Mean body wt $(\mathrm{kg})$ at outset } \\
\hline Keneba & 20 & $9 \cdot 25$ & $0 \cdot 23$ & $7 \cdot 42-11 \cdot 35$ & 19 & $9 \cdot 31$ & $0 \cdot 20$ & $7 \cdot 47-10 \cdot 70$ \\
\hline Manduar and Kanton Kundar & 34 & $9 \cdot 00$ & 0.25 & $6 \cdot 25-12 \cdot 10$ & 36 & 8.44 & 0.21 & $6 \cdot 20-11.02$ \\
\hline \multicolumn{9}{|l|}{$\mathrm{Wt}(\%$ of median for age $) \dagger$} \\
\hline Keneba & 20 & 0.79 & 0.018 & $0.673-1.013$ & 19 & 0.79 & $0 \cdot 016$ & $0.688-0.905$ \\
\hline Manduar and Kanton Kundar & 34 & 0.82 & 0.019 & $0.601-1 \cdot 154$ & 36 & 0.78 & 0.017 & $0.600-1.060$ \\
\hline
\end{tabular}

* For details, see p. 244; Keneba subjects were recruited from the age of 1.2 years, whereas those from Manduar and Kanton Kundar were recruited from 0.5 years.

$\dagger$ Expected weight-for-age based on the 50th centiles from Tanner et al. (1966).

et al. 1989), tests of immune function (Fraker et al. 1986; Kruse-Jarres, 1989), and biochemical evidence. Recent studies of undernourished children in Jamaica have recorded dramatic improvements in growth indices, and evidence of changes in body composition, during convalescence (Golden \& Golden, 1981; Golden, 1988). Studies in Bangladesh and India indicate that recovery from diarrhoeal disease can benefit from $\mathrm{Zn}$ supplements (Sachdev et al. 1988; Simmer et al. 1988; Behrens et al. 1990; Roy et al. 1992).

The purpose of the present study was to examine a variety of biochemical and functional indices in young rural Gambian children, during a controlled $\mathrm{Zn}$ supplementation trial, for 15 months.

\section{SUBJECTS AND METHODS}

\section{Selection group allocation and supplementation protocol}

Subjects were enrolled from three villages in the West Kiang rural district of The Gambia, W. Africa: Keneba, Manduar and Kanton Kundar. Those in Manduar and Kanton Kundar included essentially all subjects aged between 0.57 and 2.3 years of age. In Keneba, all subjects below 1.2 years old were excluded because there, infants between 0.25 and 1.0 years were receiving a food supplement. Although not deliberately fortified with $\mathrm{Zn}$, this might affect their Zn status. Age-ranges and other characteristics at the outset are given in Table 1. None of the children was suffering from major long-term illnesses, and they were considered as representative of a generally healthy population of young rural Gambian children.

Two matched groups, stratified by age and sex, were created by allocating subjects in successive age sequence from each sex into two groups. A double-blind protocol was used. The placebo group received a fruit-flavoured drink shown to contain negligible amounts of $\mathrm{Zn}$. The supplemented group received the same drink with $70 \mathrm{mg}$ added $\mathrm{Zn}$, initially as zinc acetate, but subsequently as zinc gluconate (since compliance was better). The drinks were given twice weekly under supervision for 15 months: August 1989 - November 1990. 
Just before the beginning of supplementation (clinic 1), and again at 2 weeks (clinic 2) and 8 weeks (clinic 3), finger-prick capillary blood samples were collected for the measurement of T-lymphocyte subsets and biochemical indices. These time-intervals were chosen to examine the possibility that changes might occur either rapidly, or transiently, in response to the supplement. They were also chosen to test for changes during the rainy season (June-September), which is the time of maximum stress, infection, growth faltering (Rowland et al. 1977) and haematological decline. Zn-free heparin (Leo Laboratories, Princes Risborough, Bucks.) was used for anti-coagulation. Although blood samples were obtained from all the subjects, the amount obtained varied (median, $300 \mu \mathrm{l}$; approximate range, $50-500 \mu \mathrm{l})$, and it was not possible to perform all the tests on all the subjects. Urine samples $(6 \mathrm{~h})$ were collected in U-bags (Downs' Surgical, Lansing, W. Sussex), with about $0.5 \mathrm{ml}$ chlorhexidine gluconate $(200 \mathrm{~g} / 1)$ as preservative. At the start of the second urine collection ( 8 weeks after the start) an oral dose of lactulose $(0.2 \mathrm{~g} / \mathrm{kg}$ body weight) and mannitol $(0.05 \mathrm{~g} / \mathrm{kg}$ body weight) was given, for the measurement of intestinal permeability (Northrop et al. 1990). Blood and urine samples were stored and transported at $-25^{\circ}$. Hair samples $(10-30 \mathrm{mg})$ were collected from $42 \%$ of the subjects at the end of the study.

\section{Anthropometry and illness records}

Body weights and mid-upper arm circumference (MUAC) were measured once weekly throughout the study; body weights were measured with a portable electronic averaging balance (SECA, Todd Scales Ltd., Newmarket, Suffolk), the subjects being lightly clothed. The MUAC records for a 3-week period around week 40 had to be discarded because of an error in recording. Body lengths were measured only at the start and end of the study (mean of three independent measurements at each time), since this measurement caused some distress. Records of illness episodes were obtained from clinic attendance records.

\section{Immunological indices}

Numbers of CD4 and CD8 lymphocytes per ml blood and, hence, the CD4:CD8 ratio were measured by the Dynabead immunomagnetic technique (Brinchmann et al. 1988); the antibody-linked magnetic beads being obtained from Dynal (UK) Ltd, Wirral, Merseyside. The isolated lymphocytes from $50 \mu \mathrm{l}$ blood were treated with Zapoglobin (Coulter Electronics, Luton, Beds.) to release their nuclei, which were stained with acridine orange dye and counted on a haemacytometer slide under a fluorescent microscope. Initially it was found that blood from Gambian infants behaved atypically by clumping irreversibly at $4^{\circ}$ during the unavoidable interval of $1-2 \mathrm{~d}$ before counting. This tendency was subsequently overcome by frequent resuspension of the nuclei during storage. Because of the initial problems with resuspension, only the results at clinic 3 are shown.

Urinary levels of secretory $\operatorname{IgA}(\mathrm{s} \operatorname{IgA})$ were measured by a minor adaptation of a procedure developed for breast milk antimicrobial factors (Prentice et al. 1984, 1991). Complement component C3 was measured by an Ames Sera-Pak immuno C3, C4 Kit (Miles Ltd, Stoke Poges, Bucks.) requiring $5 \mu \mathrm{l}$ plasma per assay.

\section{Biochemical indices}

$\mathrm{Zn}$ in plasma $(5 \mu \mathrm{l})$ was measured by electrothermal atomic absorption spectroscopy (Shaw et al. 1982), and $\mathrm{Zn}$ in hair was measured by flame atomic absorption, after digestion for $15 \mathrm{~min}$ at $40 \%$ power in a CEM (Buckingham, UK) MDS-81D microwave digestion system, using a pure $\mathrm{HNO}_{3}-\mathrm{H}_{2} \mathrm{O}$ mixture $(85: 15, \mathrm{v} / \mathrm{v})$ for dissolution. Hair samples were obtained from the back of the head, with stainless-steel scissors, and were thoroughly washed with aqueous sodium lauryl sulphate $(10 \mathrm{~g} / 1)$, followed by absolute ethanol. 
Plasma ferritin was measured by an ELISA assay requiring $22 \mu \mathrm{l}$ plasma (Anderson \& Kelly, 1981). Haemoglobin was measured by Drabkins reagent, using $20 \mu \mathrm{l}$ blood. A Roche Centrifichem no. 1421 test kit based on the Jaffé reaction was used for creatinine analysis in unhydrolysed urine. For the hydroxyproline:creatinine ratio in urine samples, an amount of urine containing about $0.2 \times 10^{-3} \mathrm{mmol}$ creatinine was hydrolysed overnight with $6 \mathrm{M}-\mathrm{HCl}$, was adjusted to $\mathrm{pH} 6.0$ with $6 \mathrm{M}-\mathrm{NaOH}$ and was then assayed for hydroxyproline in a Roche Cobas Bio centrifugal analyser (Ho \& Pang, 1989).

Plasma thymulin was measured after freeze-drying and reconstitution of equal amounts of plasma from each of six subjects, $0.1 \mathrm{ml}$ per pool, by an assay which tests the conversion of relatively azathioprine-resistant and antithyl-serum-resistant rosette-forming cells (RFC) obtained from adult thymectomized mice into thyl-positive RFC that are more sensitive to inhibition by azathioprine (Dardenne \& Bach, 1975). The effect of $\mathrm{Zn}$ addition on thymulin activity in vitro was tested (Dardenne et al. 1982a; Prasad et al. 1988). Since the thymulin levels were very low at the outset, it was felt to be unnecessary to test the specificity of the thymulin peptide by a monoclonal antibody inactivation test (Dardenne et al. 1982b).

Human growth hormone $(\mathrm{HGH})$ was measured by a kit obtained from Diagnostic Products Corporation, Los Angeles, California (HGH double antibody), scaled down to use $10 \mu \mathrm{l}$ plasma per assay. Other blood assays included superoxide dismutase (EC 1.5.1.1) in erythrocyte haemolysates by the assay of Wheeler et al. (1990) using the Cobas Bio analyser and requiring $0.8 \mu \mathrm{l}$ packed cells, plasma alkaline phosphatase $(E C$ 3.1.3.1) by an assay adapted from Levine (1974) requiring $3 \mu \mathrm{l}$ plasma, and plasma $\alpha_{1}$ antichymotrypsin and $\alpha_{1}$-acid glycoprotein by the method of Calvin \& Price (1986), also on the Cobas Bio analyser and requiring 1-2 1 l per assay.

\section{Ethical permission and informed consent}

The study was approved by the MRC Gambian Ethical Committee. The parents of the subjects were invited to give their consent, after the purpose and requirements of the study were explained to them, and they were free to withdraw their children at any time.

\section{Statistical treatment}

Cross-sectional comparisons between groups were made by Mann-Whitney U test or Student's $t$ test. Certain variables, i.e. thymulin, HGH, ferritin, lactulose:mannitol ratio, and lactulose:creatinine ratio, were transformed to natural logarithms before analysis. Because of the large number of tests performed, those differences which were significant at $P=0.01-0.05$ were designated 'marginal', and those below 0.01 as 'significant'.

For the longitudinal comparisons of weight and MUAC they were transformed to $100 . \log _{\mathrm{e}}$ (weight) and $100 . \log _{\mathrm{e}}$ (MUAC) respectively, where the log transform takes care of the skew distributions and of the standard deviations increasing with time, while the factor of 100 expresses increments in log anthropometry in percentage units. Initially, separate mean values were obtained for each week of the study using a within-subject analysis which treats each subject as its own control, with week 1 being set arbitrarily to zero. This analysis was then extended to include a week $x$ treatment group interaction to see how the pattern of growth differed in the two groups.

The time trend was then summarized by a quadratic curve in weeks plus a superimposed sine wave. This latter curve was fitted as the sine and cosine of weeks scaled to a period of 1 year, so as to optimize the phase shift. Interactions of the linear and quadratic weeks terms with treatment group were then fitted, to test for the significance of differences in growth pattern between the two groups. Further interaction terms were later fitted to test whether the observed differences in growth between the groups could be explained by underlying differences in village, sex or age. 
Table 2. Reasons for clinic visits by young rural Gambian children with or without zinc supplementation*

\begin{tabular}{|c|c|c|c|c|c|c|}
\hline \multirow[b]{2}{*}{ No. of clinic visits $\nmid$ for: } & \multicolumn{2}{|c|}{ Unsupplemented group } & \multicolumn{2}{|c|}{ Zn-supplemented group } & \multirow[b]{2}{*}{$Z \ddagger$} & \multirow{2}{*}{$\begin{array}{c}\text { Statistical significance } \\
\text { of difference: } \\
P+\end{array}$} \\
\hline & Mean & Range & Mean & Range & & \\
\hline Diarrhoea & $1 \cdot 22$ & $0-5$ & $1 \cdot 51$ & $0-8$ & $0 \cdot 25$ & $0 \cdot 80$ \\
\hline Malaria & 0.94 & $0-7$ & $0 \cdot 64$ & $0-4$ & $1 \cdot 68$ & 0.09 \\
\hline Respiratory illness & $3 \cdot 54$ & $0 \cdot 12$ & $4 \cdot 13$ & $0-17$ & $0 \cdot 46$ & 0.92 \\
\hline 'Malnutrition'\| & 0.26 & $0-4$ & 0.62 & $0-9$ & 0.97 & $0 \cdot 34$ \\
\hline All reasons combined & $11 \cdot 96$ & $1-30$ & $13 \cdot 31$ & $3-36$ & 0.58 & $0 \cdot 56$ \\
\hline
\end{tabular}

* For details of subjects and treatments, see Table 1 and pp. 244-245.

$\dagger$ Expressed as the arithmetic mean of visits per subject. Data generally were positively skewed.

\$ Based on Mann-Whitney $U$ test (two-tailed), for no. of visits per subject.

$\S$ Confirmed by microscopic examination.

I. Generally either 'underweight' or 'marasmus'.

\section{RESULTS}

Compliance. Of 112 subjects originally enrolled, two moved away from the village before the seventh week of the study (one from each supplement group); their data are omitted from the summaries and calculations. Six others (two from each of the three villages) moved away between 24 and 31 weeks of supplementation, and two others (one from Manduar, and one from Keneba) moved away at weeks 42 and 45 . These eight subjects were equally distributed between the two supplement groups (four placebo, four supplemented) and their data are included. Likewise the data from the one child (Kanton Kanduar, placebo group) who died of malaria in the 54th week of study are retained.

Illness records. Table 2 shows the mean number of clinic visits due to illness divided into several categories, for the two groups. By far the majority of the episodes occurred during the two rainy seasons (1989 and 1990). The number of diarrhoeal episodes during the first half of the study was negatively correlated with weight gain during the same period $(P<$ $0.01)$ but was positively correlated with weight gain over the entire study $(P<0.05)$ and with MUAC gain over the entire study $(P=0.01)$. Of the five categories of illness shown in Table 2, only malaria episodes exhibited an inter-group difference which approached significance. If the episodes in the first month of the study were excluded, then the number of visits resulting in a positive malaria diagnosis was lower in the supplemented group with a significance (two-tailed) of $Z 1.92, P=0.054$.

Anthropometry. Fig. 1 (a) shows the mean percentage change in body weight (all subjects) during the study. There clearly was a period of growth-faltering near the start (0-6 weeks), during late August - early October 1989, and again between 50 and 60 weeks, between early August and mid-October 1990. These correspond with rainy-season growth-faltering periods previously observed in other studies of this community. The growth patterns were best described mathematically as a linear increase with a superimposed sine-wave representing the seasonal fluctuation.

Comparison of the weight gains in the two groups for each week of the study indicated that although there were more values above the zero line than below, indicating a favourable trend for the supplement, this did not achieve significance. There was no indication of any progressive beneficial effect of the supplement, indeed the greatest benefit occurred in the middle of the study, which corresponded to the middle of the dry season, February 1990. During the first period of weight-faltering at the beginning of the study, 

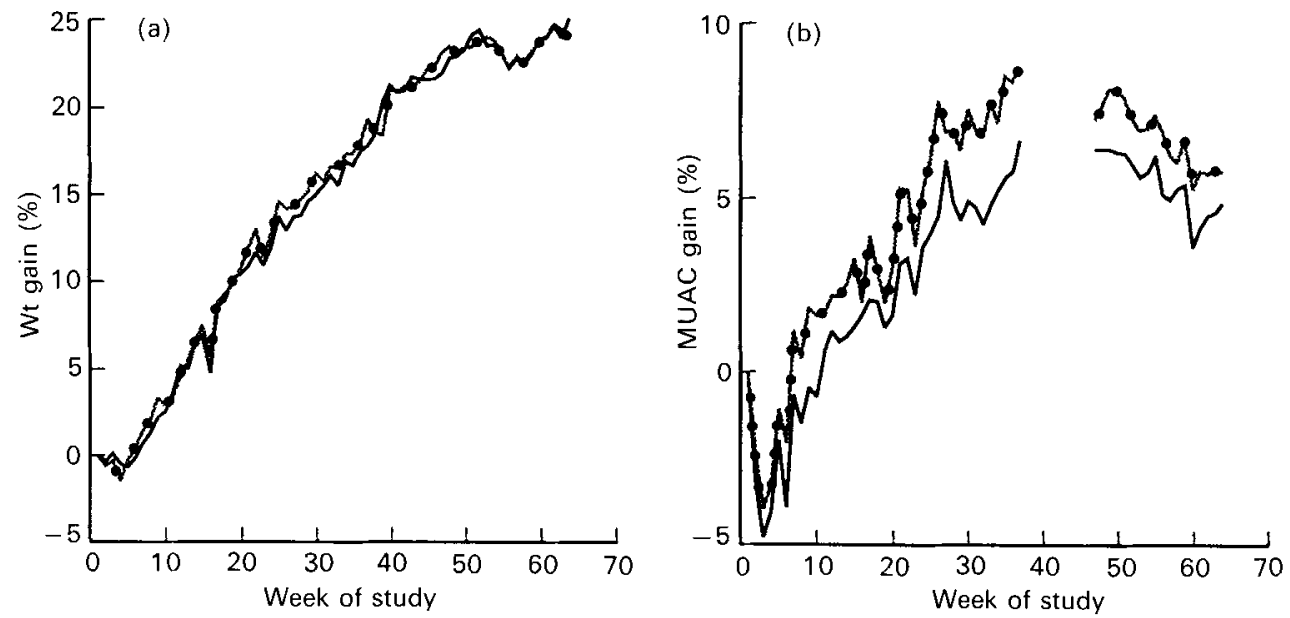

Fig. 1. Percentage change in (a) body weight and (b) mid-upper-arm circumference (MUAC) at weekly intervals during the study for young rural Gambian children with (C) or without ( $\rightarrow$ ) zinc supplementation (for details, see Table 1). Each point is the mean value for all subjects in the study; 110 at the start; 102 by week 65 . Weeks 0-9 were in the rainy season (July-September 1989); the dry season extended from approximately week 10 to week 45 , and the rainy season in 1990 extended from week 46 to week 62 .

three subjects in the unsupplemented group lost more than $0.1 \mathrm{~kg} /$ week over a 4 -week period, whereas none of those in the supplemented group lost more than $0.1 \mathrm{~kg} /$ week over this period. During the second period of weight-faltering (weeks 52-58), four subjects in the unsupplemented group and six in the supplemented group lost more than $0.1 \mathrm{~kg} /$ week.

Fig. $1(b)$ shows the mean values for MUAC throughout the study. For this index the second period of growth-faltering was much more marked than for the weight changes; it continued from week 40 until the end of the study in November 1990. Nearly all the weekly values showed a positive effect of the supplement, and the overall difference was represented by a $t$ value of 2.7 and $P<0.01$ (109 df). However, the $\mathrm{Zn}$ effect was small; only $2 \%$ of the overall mean MUAC value $(135 \mathrm{~mm}$ at the outset and $144 \mathrm{~mm}$ by the end of the study), and it did not increase progressively. The data in Table 3 confirm that there were no significant inter-group differences in the overall increases in body weight and MUAC between the start and the finish of the study.

There was some indication that the male infants enjoyed a greater benefit from the supplement than the female infants, but there were no clear associations of benefit with particular villages or particular age-groups. Body length changes (Table 3) were very similar in both groups and showed no significant $\mathrm{Zn}$ effect. The same was true for each sex, village or age-group when analysed separately.

Overall weight gain was strongly correlated with overall gain in MUAC $(P<0.0001)$, and with overall height gain $(P<0.005)$, between subjects.

\section{Blood haemoglobin, lymphocyte counts and plasma complement (C3) levels}

Haemoglobin measurements were available for clinics 1 and 2 only (Table 4). Lymphocyte sub-set counts are recorded for clinic 3 only (Table 4). Plasma C3 complement was measured at all three clinics, but the data for clinic 1 were less complete than those for clinics 2 and 3 (Table 4).

sIgA in urine is expressed in Table 4 as $\mu \mathrm{g} / 6 \mathrm{~h}$ collection period, representing only the specific secretory material, free from plasma $\operatorname{IgA}$ or $\operatorname{IgA}$ fragments. For all four groups of urines, the total:secretory ratio was in the range $1.02-1.25$, indicating very little 
Table 3. Body length, weight and mid-upper-arm circumference (MUAC) for young rural Gambian children with or without zinc supplementation*

(Mean values with their standard errors)

\begin{tabular}{|c|c|c|c|c|c|c|c|}
\hline & \multicolumn{3}{|c|}{ Unsupplemented group } & \multicolumn{3}{|c|}{ Zn-supplemented group } & \multirow{2}{*}{$\begin{array}{l}\text { Statistical analysis } \\
\text { of inter-group } \\
\text { differences } \dagger: t\end{array}$} \\
\hline & $n$ & Mean & $\mathrm{SE}$ & $n$ & Mean & $\mathrm{SE}$ & \\
\hline \multicolumn{8}{|c|}{ Body length $(\mathrm{mm})$ : } \\
\hline Aug 1989 & 46 & 777 & $6 \cdot 2$ & 51 & 758 & $6 \cdot 2$ & \\
\hline Nov 1990 & 46 & 882 & $6 \cdot 2$ & 51 & 858 & $6 \cdot 2$ & \\
\hline Change & 46 & 105 & $2 \cdot 9$ & 51 & 100 & $2 \cdot 9$ & 1.08 \\
\hline \multicolumn{8}{|l|}{ Body wt (kg): } \\
\hline Aug 1989 & 50 & $9 \cdot 15$ & $0 \cdot 18$ & 53 & 8.68 & $0 \cdot 16$ & \\
\hline Nov 1990 & 50 & 11.63 & 0.19 & 53 & 11.07 & 0.19 & \\
\hline Change & 50 & $2 \cdot 38$ & $0 \cdot 13$ & 53 & $2 \cdot 39$ & $0 \cdot 10$ & $0 \cdot 06$ \\
\hline \multicolumn{8}{|c|}{$\operatorname{MUAC}(\mathrm{mm})$ : } \\
\hline Aug 1989 & 49 & 137 & 1.4 & 53 & 133 & 1.6 & \\
\hline Nov 1990 & 49 & 145 & $1 \cdot 3$ & 53 & 143 & $1 \cdot 5$ & \\
\hline Change & 49 & $7 \cdot 7$ & $1 \cdot 4$ & 53 & 8.7 & $1 \cdot 0$ & 0.58 \\
\hline
\end{tabular}

* For details of subjects and treatments, see Table 1 and pp. 244-245.

$\dagger$ These comparisons have been limited to those subjects who yielded measurements at both the time points indicated. No significant differences attributable to the $\mathrm{Zn}$ supplement were detected.

Table 4. Haemoglobin and immunity factors (lymphocyte counts, plasma C3 and urinary sIgA) for young rural Gambian children with or without zinc supplementation*

(Arithmetic mean values with their standard errors (SE) or geometric mean values with their SE and $95 \%$ confidence intervals $(\mathrm{CI})$ )

\begin{tabular}{|c|c|c|c|c|c|c|c|c|}
\hline & \multirow{2}{*}{$\begin{array}{l}\text { Clinic } \\
\text { no. }\end{array}$} & \multicolumn{3}{|c|}{$\begin{array}{l}\text { Unsupplemented } \\
\text { group }\end{array}$} & \multicolumn{3}{|c|}{$\begin{array}{l}\mathrm{Zn} \text {-supplemented } \\
\text { group }\end{array}$} & \multirow{2}{*}{$\begin{array}{l}\text { Statistical analysis } \\
\text { of intergroup } \\
\text { differences } \$: t\end{array}$} \\
\hline & & $n$ & Mean & SE or CI & $n$ & Mean & SE or CI & \\
\hline Haemoglobin ( $\mathrm{g} / \mathrm{l}$ blood) & $\begin{array}{l}1 \\
2\end{array}$ & $\begin{array}{l}48 \\
55\end{array}$ & $\begin{array}{l}120 \\
116\end{array}$ & $\begin{array}{l}3 \cdot 2 \\
2 \cdot 0\end{array}$ & $\begin{array}{l}45 \\
50\end{array}$ & $\begin{array}{l}116 \\
117\end{array}$ & $\begin{array}{l}3 \cdot 5 \\
3 \cdot 3\end{array}$ & $\begin{array}{l}0 \cdot 83 \\
0 \cdot 26\end{array}$ \\
\hline $\begin{array}{l}\text { Lymphocytes }(/ \mu 1 \text { blood }) \dagger \\
\text { CD4 } \\
\text { CD8 } \\
\text { CD4:CD8 }\end{array}$ & & $\begin{array}{l}49 \\
49 \\
49\end{array}$ & $\begin{array}{l}1047 \\
426 \\
2 \cdot 72\end{array}$ & $\begin{array}{l}73 \\
36 \\
0 \cdot 17\end{array}$ & $\begin{array}{l}52 \\
52 \\
52\end{array}$ & $\begin{array}{l}956 \\
504 \\
2 \cdot 47\end{array}$ & $\begin{array}{l}69 \\
50 \\
0 \cdot 26\end{array}$ & $\begin{array}{l}1 \cdot 03 \\
1 \cdot 17 \\
0 \cdot 73\end{array}$ \\
\hline C3 complement (mg/l plasma) & $\begin{array}{l}1 \\
2 \\
3\end{array}$ & $\begin{array}{l}28 \\
48 \\
52\end{array}$ & $\begin{array}{l}1490 \\
1310 \\
1540\end{array}$ & $\begin{array}{l}87 \\
52 \\
63\end{array}$ & $\begin{array}{l}29 \\
47 \\
52\end{array}$ & $\begin{array}{l}1370 \\
1430 \\
1400\end{array}$ & $\begin{array}{l}65 \\
58 \\
57\end{array}$ & $\begin{array}{l}1 \cdot 15 \\
1 \cdot 53 \\
1.66\end{array}$ \\
\hline Secretory $\operatorname{IgA}$ in urine $(\mu \mathrm{g} / 6 \mathrm{~h})+$ & $\begin{array}{l}1 \\
3\end{array}$ & $\begin{array}{l}19 \\
19\end{array}$ & $\begin{array}{l}38 \cdot 0 \\
24 \cdot 8\end{array}$ & $\begin{array}{l}24 \cdot 5-58 \cdot 9 \\
15 \cdot 6-39 \cdot 5\end{array}$ & $\begin{array}{l}25 \\
25\end{array}$ & $\begin{array}{l}24 \cdot 8 \\
21 \cdot 5\end{array}$ & $\begin{array}{l}15 \cdot 8-39 \cdot 0 \\
12 \cdot 9-35 \cdot 9\end{array}$ & $\begin{array}{l}0.90 \\
0 \cdot 46\end{array}$ \\
\hline
\end{tabular}

* For details of subjects and treatments, see Table I and pp. 244-245.

$\dagger$ At clinic 3 only; insufficient plasma available to assay all the clinic 1 samples.

Keneba and Kanton Kundar subjects only.

$\$$ No significant inter-group differences attributable to the $\mathrm{Zn}$ supplement were detected, for any of these indices. 
Table 5. Plasma hormone levels for young rural Gambian children with or without zinc supplementation*

(Geometric means with $95 \%$ confidence intervals $(\mathrm{CI})$ )

\begin{tabular}{|c|c|c|c|c|c|c|c|c|}
\hline & \multirow[b]{2}{*}{$\begin{array}{c}\text { Clinic } \\
\text { no. }\end{array}$} & \multicolumn{3}{|c|}{ Unsupplemented group } & \multicolumn{3}{|c|}{ Zn-supplemented group } & \multirow{2}{*}{$\begin{array}{l}\text { Statistical analysis } \\
\text { of inter-group } \\
\text { differences } \$ t\end{array}$} \\
\hline & & $n$ & $\begin{array}{c}\text { Geometric } \\
\text { mean }\end{array}$ & $\mathrm{CI}$ & $n$ & $\begin{array}{c}\text { Geometric } \\
\text { mean }\end{array}$ & $\mathrm{CI}$ & \\
\hline Thymulin (titre) $\dagger$ & $\begin{array}{l}1 \\
2 \\
3\end{array}$ & $\begin{array}{l}5 \\
5 \\
5\end{array}$ & $\begin{array}{r}4 \cdot 6 \\
13 \cdot 9 \\
42 \cdot 2\end{array}$ & $\begin{array}{c}3 \cdot 5-6 \cdot 0 \\
7 \cdot 0-27 \cdot 4 \\
35 \cdot 9-50 \cdot 4\end{array}$ & $\begin{array}{l}5 \\
5 \\
5\end{array}$ & $\begin{array}{r}4 \cdot 0 \\
16 \cdot 0 \\
36 \cdot 8\end{array}$ & $\begin{array}{c}4 \cdot 0-4 \cdot 0 \\
10 \cdot 3-24 \cdot 8 \\
21 \cdot 8-61 \cdot 6\end{array}$ & $\begin{array}{l}1 \cdot 00 \\
0 \cdot 34 \\
0 \cdot 45\end{array}$ \\
\hline $\mathrm{HGH}(\mathrm{ng} / \mathrm{ml}) \neq$ & $\begin{array}{l}1 \\
2 \\
3\end{array}$ & $\begin{array}{r}9 \\
14 \\
37\end{array}$ & $\begin{array}{l}4 \cdot 35 \\
7 \cdot 54 \\
2 \cdot 60\end{array}$ & $\begin{array}{l}2 \cdot 1-9 \cdot 1 \\
5 \cdot 0-11 \cdot 2 \\
1 \cdot 8-3 \cdot 6\end{array}$ & $\begin{array}{l}10 \\
22 \\
29\end{array}$ & $\begin{array}{l}3.95 \\
4 \cdot 78 \\
2 \cdot 56\end{array}$ & $\begin{array}{l}2 \cdot 6-6 \cdot 0 \\
2 \cdot 9-7 \cdot 7 \\
1 \cdot 8-3 \cdot 7\end{array}$ & $\begin{array}{l}0.16 \\
0.84 \\
0.00\end{array}$ \\
\hline
\end{tabular}

* For details of subjects and treatments, see Table 1 and pp. 244-246.

† Expressed as the highest dilutions of plasma for a borderline-detectable effect in the standard assay. Each measurement was performed on a pool of ten samples of plasma of equal volumes.

$\ddagger$ Four zero values assigned a value of $0.1 \mathrm{ng} / \mathrm{ml}$ (detection limit).

$\S$ No significant inter-group differences attributable to the zinc supplement were detected.

contamination with degradation products, or with plasma IgA. The sIgA output per unit creatinine showed a similar pattern.

There was no indication of a $\mathrm{Zn}$ supplementation effect on any of these indices.

\section{Plasma hormone levels}

For the thymulin assay, pooled samples were used to obtain sufficient for each assay. As shown in Table 5 , log plasma thymulin titres increased dramatically (by $2 \cdot 5$-fold in both groups), between clinic 1 and clinic 3 . The increase was similar for both supplement groups. The ratio, titres with $\mathrm{Zn}$ added in vitro:those without, decreased between clinics 1 and 3 from 3.64 to 1.25 in the unsupplemented group, and from 3.33 to 1.43 in the supplemented group. The overall changes between clinics were highly significant $(P<0.01)$, but the differences between supplement groups (in vivo $\mathrm{Zn}$ effects) were not significant.

For growth hormone (Table 5) only partial data-sets were obtained, and these do not indicate any effect of the $\mathrm{Zn}$ supplement.

\section{Plasma proteins and enzyme activities}

Data for superoxide dismutase activity in erythocytes were almost complete for clinics 1 and 3 (Table 6); partial data-sets were available for plasma alkaline phosphatase and for plasma ferritin for all three clinics (Table 6). None of these indices exhibited a significant effect of the $\mathrm{Zn}$ supplement. There was a significant but transient increase in plasma $\alpha_{1}$ antichymotrypsin $(P<0.01)$ and $\alpha_{1}$-acid glycoprotein $(P<0.02$, not shown $)$ in the supplemented group compared with the placebo group at clinic 2 , but not at clinic 3 .

Urinary hydroxyproline: creatinine ratio, and intestinal permeability measured by urinary lactulose: mannitol ratios after oral sugar dosing

The increase in urinary hydroxyproline:creatinine ratio (Table 7) between clinic 1 and clinic 3 was greater in the supplemented than in the placebo group, but not significantly so. There was a marginally significant effect of the supplement for the girls: for the unsupplemented groups the mean change was +0.037 (SE 0.022, $n 21) \mathrm{mol} / \mathrm{mol}$ and for the 
Table 6. Blood enzyme activities and ferritin levels for young rural Gambian children with or without zinc supplementation $\dagger$

(Arithmetic means with their standard errors (SE) or geometric means with their SE and $95 \%$ confidence intervals (CI))

\begin{tabular}{|c|c|c|c|c|c|c|c|c|}
\hline & \multirow{2}{*}{$\begin{array}{l}\text { Clinic } \\
\text { no. }\end{array}$} & \multicolumn{3}{|c|}{$\begin{array}{l}\text { Unsupplemented } \\
\text { group }\end{array}$} & \multicolumn{3}{|c|}{$\begin{array}{l}\text { Zn-supplemented } \\
\text { group }\end{array}$} & \multirow{2}{*}{$\begin{array}{c}\text { Statistical } \\
\text { analysis } \\
\text { of inter-group } \\
\text { differences: } t\end{array}$} \\
\hline & & $n$ & Mean & $\mathrm{SE}$ or $\mathrm{CI}$ & $n$ & Mean & $\mathrm{SE}$ or $\mathrm{CI}$ & \\
\hline $\begin{array}{l}\text { Superoxide dismutase in } \\
\text { erythrocytes ( } \mathrm{IU} / \mathrm{mg} \text { haemoglobin) }\end{array}$ & $\begin{array}{l}1 \\
3\end{array}$ & $\begin{array}{l}52 \\
53\end{array}$ & $\begin{array}{l}3 \cdot 74 \\
3 \cdot 25\end{array}$ & $\begin{array}{l}0.07 \\
0.09\end{array}$ & $\begin{array}{l}54 \\
53\end{array}$ & $\begin{array}{l}3 \cdot 60 \\
3 \cdot 29\end{array}$ & $\begin{array}{l}0.07 \\
0.08\end{array}$ & $\begin{array}{l}0 \cdot 60 \\
0 \cdot 33\end{array}$ \\
\hline $\begin{array}{l}\text { Alkaline phosphatase in plasma } \\
(\mathrm{IU} / \mathrm{l})\end{array}$ & $\begin{array}{l}1 \\
2 \\
3\end{array}$ & $\begin{array}{l}31 \\
46 \\
44\end{array}$ & $\begin{array}{l}79 \cdot 7 \\
75 \cdot 6 \\
79 \cdot 1\end{array}$ & $\begin{array}{l}5 \cdot 1 \\
4 \cdot 5 \\
4 \cdot 8\end{array}$ & $\begin{array}{l}26 \\
46 \\
42\end{array}$ & $\begin{array}{l}74 \cdot 7 \\
78 \cdot 5 \\
67 \cdot 5\end{array}$ & $\begin{array}{l}4 \cdot 3 \\
4 \cdot 1 \\
3 \cdot 0\end{array}$ & $\begin{array}{c}0.75 \\
0.51 \\
1.48\end{array}$ \\
\hline$\alpha_{1}$-Antichymotrypsin in plasma $(\mathrm{g} / \mathrm{l})$ & $\begin{array}{l}1 \\
2 \\
3\end{array}$ & $\begin{array}{l}29 \\
41 \\
40\end{array}$ & $\begin{array}{l}0.78 \\
0.84 \\
0 \cdot 89\end{array}$ & $\begin{array}{l}0.058 \\
0.043 \\
0.041\end{array}$ & $\begin{array}{l}28 \\
41 \\
41\end{array}$ & $\begin{array}{l}0.77 \\
1.02 \\
0.84\end{array}$ & $\begin{array}{l}0.045 \\
0.053 \\
0.048\end{array}$ & $\begin{array}{l}0 \cdot 14 \\
2 \cdot 65^{* *} \\
0 \cdot 79\end{array}$ \\
\hline Ferritin in plasma $(\mu \mathrm{g} / 1)$ & $\begin{array}{l}1 \\
2 \\
3\end{array}$ & $\begin{array}{r}9 \\
19 \\
45\end{array}$ & $\begin{array}{l}15 \cdot 1 \\
30 \cdot 7 \\
15 \cdot 9\end{array}$ & $\begin{array}{r}7 \cdot 6-29 \cdot 7 \\
21 \cdot 5-44 \cdot 3 \\
11 \cdot 5-21 \cdot 8\end{array}$ & $\begin{array}{l}14 \\
22 \\
40\end{array}$ & $\begin{array}{l}18 \cdot 2 \\
28 \cdot 2 \\
17 \cdot 2\end{array}$ & $\begin{array}{l}12 \cdot 4-26 \cdot 6 \\
21 \cdot 1-37 \cdot 0 \\
13 \cdot 2-23 \cdot 1\end{array}$ & $\begin{array}{l}0.49 \\
0.40 \\
0.43\end{array}$ \\
\hline
\end{tabular}

The inter-group difference attributable to the $\mathrm{Zn}$ supplement was significant: (Student's $t$ test) ${ }^{* *} P<0 \cdot 01$.

$\dagger$ For details of subjects and treatments, see Table 1 and pp. 244-246.

Table 7. Urinary indices of collagen turnover and of intestinal permeability for young rural Gambian children with or without zinc supplementation

(Arithmetic means with their standard errors (SE) or geometric means with their SE and $95 \%$ confidence intervals $(\mathrm{CI})$ )

\begin{tabular}{|c|c|c|c|c|c|c|c|c|}
\hline & \multirow{2}{*}{$\begin{array}{c}\text { Clinic } \\
\text { no }\end{array}$} & \multicolumn{3}{|c|}{$\begin{array}{l}\text { Unsupplemented } \\
\text { group }\end{array}$} & \multicolumn{3}{|c|}{$\begin{array}{l}\text { Zn-supplemented } \\
\text { group }\end{array}$} & \multirow{2}{*}{$\begin{array}{l}\text { Statistical } \\
\text { analysis } \\
\text { of inter-group } \\
\text { differences: } t\end{array}$} \\
\hline & & $n$ & Mean & $\mathrm{SE}$ or CI & $n$ & Mean & $\mathrm{SE}$ or $\mathrm{CI}$ & \\
\hline $\begin{array}{l}\text { Hydroxyproline: creatinine (molar ratio) } \\
\text { change }\end{array}$ & $\begin{array}{c}1 \\
3 \\
3-1\end{array}$ & $\begin{array}{l}38 \\
39 \\
38\end{array}$ & $\begin{array}{l}0.426 \\
0.461 \\
0.034\end{array}$ & $\begin{array}{l}0 \cdot 022 \\
0 \cdot 022 \\
0 \cdot 017\end{array}$ & $\begin{array}{l}46 \\
45 \\
45\end{array}$ & $\begin{array}{l}0 \cdot 392 \\
0 \cdot 463 \\
0 \cdot 070\end{array}$ & $\begin{array}{l}0.016 \\
0.023 \\
0.022\end{array}$ & 1.29 \\
\hline Lactulose: creatinine (molar ratio) & 3 & 39 & $0 \cdot 56$ & $0.46-0.68$ & 43 & 0.35 & $0 \cdot 25-0 \cdot 48$ & $2 \cdot 52^{* *}$ \\
\hline Mannitol:creatinine (molar ratio) & 3 & 39 & $1 \cdot 25$ & $0 \cdot 132$ & 44 & $1 \cdot 01$ & 0.097 & $1 \cdot 48$ \\
\hline Lactulose : mannitol (molar ratio) & 3 & 39 & 0.54 & $0.42-0.68$ & 44 & 0.44 & $0 \cdot 34-0.56$ & $1 \cdot 18$ \\
\hline
\end{tabular}

The inter-group difference attributable to the $\mathrm{Zn}$ supplement was significant: ${ }^{* *} P<0 \cdot 02$.

supplemented group it was $+0 \cdot 112(\mathrm{SE} 0 \cdot 027, n 25) ;(t 2 \cdot 15,43 \mathrm{df}, P<0 \cdot 05)$. There was a significant positive correlation between the mean value of the hydroxyproline:creatinine ratio for each subject and the rate of body weight gain $(P<0 \cdot 01)$ or length gain $(P<0 \cdot 001)$ over the same period, but no correlation with MUAC gain.

Intestinal permeability towards lactulose was significantly lower in the supplemented group $(P<0.02$; Table 7$)$. This supplement effect was observed consistently in all three study villages and both sexes. The results for absorption of mannitol and lactulose:mannitol ratio, however, were less clearcut. There was a large difference between the three study villages, and some evidence for a deleterious effect of the supplement (reduced 
Table 8. Plasma and hair metal levels for young rural Gambian children with or without zinc supplementation*

(Mean values with their standard errors)

\begin{tabular}{|c|c|c|c|c|c|c|c|c|}
\hline & & \multicolumn{3}{|c|}{$\begin{array}{l}\text { Unsupplemented } \\
\text { group }\end{array}$} & \multicolumn{3}{|c|}{$\begin{array}{c}\mathrm{Zn} \text {-supplemented } \\
\text { group }\end{array}$} & \multirow{2}{*}{$\begin{array}{l}\text { Statistical analysis } \\
\text { of inter-group } \\
\text { differences } †: t\end{array}$} \\
\hline & & $n$ & Mean & SE & $n$ & Mean & SE & \\
\hline Plasma $\mathrm{Zn}(\mu \mathrm{mol} / \mathrm{l})$ & $\begin{array}{l}\text { Clinic } 2 \\
\text { Clinic } 3\end{array}$ & $\begin{array}{l}28 \\
44\end{array}$ & $\begin{array}{l}15 \cdot 2 \\
16 \cdot 3\end{array}$ & $\begin{array}{l}1 \cdot 6 \\
1 \cdot 3\end{array}$ & $\begin{array}{l}30 \\
46\end{array}$ & $\begin{array}{l}15 \cdot 2 \\
17 \cdot 8\end{array}$ & $\begin{array}{l}1 \cdot 8 \\
1 \cdot 3\end{array}$ & $\begin{array}{l}0.00 \\
0.82\end{array}$ \\
\hline Hair Zn $(\mu \mathrm{mol} / \mathrm{g})$ & End of study & 22 & $2 \cdot 60$ & $0 \cdot 18$ & 22 & 2.45 & $0 \cdot 22$ & $0 \cdot 54$ \\
\hline Hair $\mathrm{Cu}(\mu \mathrm{mol} / \mathrm{g})$ & End of study & 20 & $0 \cdot 28$ & $0 \cdot 021$ & 22 & 0.26 & 0.038 & $0 \cdot 30$ \\
\hline
\end{tabular}

* For details of subjects and treatments, see Table 1 and pp. 244-245.

$\dagger$ No significant inter-group differences attributable to the supplement were detected.

absorption, $P=0.03$ ) in Keneba. Neither mannitol nor the lactulose:mannitol ratio exhibited any significant supplement effect when all three villages were considered (Table 7). Thus, $\mathrm{Zn}$ appeared to reduce the leakage route taken by lactulose without affecting the normal brush-border absorption route for mannitol. The range of values in the present study was similar to that obtained in a previous study of Gambian children (Lunn et al. 1991).

\section{Zn concentrations in plasma and hair samples}

Plasma $\mathrm{Zn}$ measurements at clinics 2 and 3 and hair $\mathrm{Zn}$ and $\mathrm{Cu}$ measurements at the end of the study are shown in Table 8. These are incomplete data-sets because of limited availability of samples; in each case there was no significant effect of the $\mathrm{Zn}$ supplement.

\section{Discussion}

Adequacy of $\mathrm{Zn}$ status in humans can only be determined by a range of functional tests before and during supplementation, since $\mathrm{Zn}$ concentrations at sites such as hair and plasma can be misleading (Aggett, 1990). Zn has many diverse roles in metabolic processes; the amounts at accessible sites may not reflect the supply at other more critically-susceptible ones.

Evidence for $\mathrm{Zn}$ supplementation responses during the correction of $\mathrm{Zn}$ deficiency in humans has been reported for the following indices: (a) growth (including growth recovery during diarrhoeal disease) (Golden \& Golden, 1981; Hambidge, 1988; Sachdev et al. 1988; Simmer et al. 1988; Behrens et al. 1990; Prasad, 1991); (b) immune function, including cellmediated and secretory immunoglobulin responses (Fraker et al. 1986; Prasad, 1991); (c) plasma thymulin (a Zn-containing hormone which controls cell-mediated immune function (Dardenne et al. 1982a: Prasad et al. 1988); (d) growth hormone levels and function (Ghavami-Maibodi et al. 1983); (e) alkaline phosphatase (Weisman \& Hoyer, 1985). Evidence for a decline in serum complement components during $\mathrm{Zn}$ deficiency has been reported (Kruse-Jarres, 1989), but is less well-established than the other effects of $\mathrm{Zn}$. Erythrocyte superoxide dismutase appears to exhibit $\mathrm{Cu}$ dependence but not $\mathrm{Zn}$ dependence in animal studies (Bray \& Bettger, 1990).

In the present study the absence of a $\mathrm{Zn}$ supplementation effect on superoxide dismutase gives some reassurance that $\mathrm{Cu}$ status was not deleteriously affected by the $\mathrm{Zn}$ supplement. The same was true for hair $\mathrm{Cu}$ at the end of the study. Likewise, there were no changes in 
indices of $\mathrm{Fe}$ status (plasma ferritin; blood haemoglobin) to suggest $\mathrm{Zn}$ competition for $\mathrm{Fe}$ absorption (Yardrick et al. 1989).

There was a trend towards fewer malaria episodes in the $\mathrm{Zn}$-supplemented group and, although not significant, this seems worthy of further investigation. Hydroxyproline excretion in the girls seemed to indicate a marginally-beneficial effect during the early stages of supplementation. MUAC appeared to benefit slightly in the boys. The picture for plasma thymulin levels was puzzling: at the start there were very low levels of active hormone, and a large in vitro response to $\mathrm{Zn}$ which disappeared as the dry season was entered. Other investigators (Prasad et al. 1988) have noted a significant decrease in serum thymulin activity during mild $\mathrm{Zn}$ deficiency in humans, but longitudinal studies of seasonal variations have not been performed.

The improvement in lactulose:creatinine ratios in the $\mathrm{Zn}$-supplemented group also requires further study. Although it may suggest a beneficial effect on mucosal integrity, the overall permeability index provided by the lactulose:mannitol ratio was not affected. The significant but transient increase in plasma $\alpha_{1}$-antichymotrypsin and $\alpha_{1}$-acid glycoprotein at clinic 2 may result from enhanced hepatic protein synthesis in the supplemented group, but it may equally represent an acute-phase reaction.

The overall picture is one of reasonably adequate $\mathrm{Zn}$ status (confirmed by the relatively high plasma and hair $\mathrm{Zn}$ levels), and although some minor beneficial responses to the $\mathrm{Zn}$ supplement were observed, they were not entirely clearcut. One possibility, based on the observations and conclusions of Watkinson et al. (1985), Castillo-Duran et al. (1987), Golden (1988) and Aggett (1990), is that $\mathrm{Zn}$ may not be limiting if there is an inadequate supply of certain other nutrients. A transient benefit of $\mathrm{Zn}$ may, thus, represent a response which could only be sustained if other nutrients were also provided. Growth-faltering during the rainy season clearly cannot be prevented by $\mathrm{Zn}$ supplementation alone.

The amount of $\mathrm{Zn}$ given, equivalent to $20 \mathrm{mg}$ elemental $\mathrm{Zn} / \mathrm{d}$, was five times greater than the estimated average requirement of UK children between 7 months and 3 years old (Department of Health, 1991), and should, therefore, correct a simple dietary deficiency, despite the existence of dietary components which limit $\mathrm{Zn}$ bioavailability (Department of Health, 1991) or of losses during bouts of diarrhoeal disease.

$\mathrm{Zn}$ status in Gambians may be better than is predicted from their plant-based diet. A recent study of breast-milk $\mathrm{Zn}$ from lactating Gambians, for example, found higher levels than in breast milk from UK mothers at equivalent stages of lactation (Bates \& Tsuchiya, 1990).

From the practical viewpoint, most young Gambian children would gain little from $\mathrm{Zn}$ supplements alone. A sub-group which may be at increased risk of functional $\mathrm{Zn}$ deficiency are sufferers from chronic diarrhoea (McClain et al. 1985; Gatheru et al. 1988; Sachdev et al. 1988; Behrens et al. 1990; Roy et al. 1992). Selection procedures are needed to identify potentially-responsive individuals, and future experimental designs should explore the effects of $\mathrm{Zn}$ supplements combined with other nutrients, in high-risk populations.

The authors wish to thank the subjects and their parents for their patient co-operation and Mr E. Jarjou and Mr B. Kanteh for their technical assistance.

\section{REFERENCES}

Aggett, P. J. (1990). Malnutrition and trace element metabolism. In The Malnourished Child. Nestlé Nutrition Workshop Series no. 18, pp. 155-176 [R. M. Suskind and L. Lewinter-Suskind, editors]. New York: Vevey/Raven Press Ltd.

Anderson, M. G. \& Kelly, A. M. (1981). Serum ferritin by a rapid and inexpensive ELISA method. Clinica Chimica Acta 116, 405-408. 
Bates, C. J. \& Tsuchiya, H. (1990). Zinc in breast milk during prolonged lactation: comparison between the UK and The Gambia. European Journal of Clinical Nutrition 44, 61-69.

Behrens, R. H., Tomkins, A. M. \& Roy, S. K. (1990). Zinc supplementation during diarrhoea, a fortification during malnutrition? Lancet ii, $442-443$.

Bray, T. M. \& Bettger, W. J. (1990). The physiological role of zinc as an antioxidant. Free Radicals in Biology and Medicine 8, 281-291.

Brinchmann, J. E., Vartdal, F., Gaudernack, G., Markussen, G., Funderud, S., Ugelstad, J. \& Thorsby, E. (1988). Direct immunomagnetic quantification of lymphocyte subsets in blood. Clinical and Experimental Immunology 71, 182-186.

Calvin, J. \& Price, C. P. (1986). Measurement of serum $\alpha_{1}$-antichymotrypsin by immunoturbidimetry. Annals of Clinical Biochemistry 23, 206-209.

Castillo-Duran, C., Heresi, G., Fisberg, M. \& Uauy, R. (1987). Controlled trial of zinc supplementation during recovery from malnutrition: effects on growth and immune function. American Journal of Clinical Nutrition 45, 602-608.

Dardenne, M. \& Bach, J. F. (1975). The sheep cell rosette assay for the evaluation of thymic hormones. In Biological Activity of Thymic Hormones, pp. 235-243 [D. Van Bekkum, editor]. Rotterdam: Kooyer Scientific Publications.

Dardenne, M., Pleau, J. M. \& Nabarra, P. (1982a). Contribution of zinc and other metals to the biological activity of the serum thymic factor. Proceedings of the National Academy of Sciences, USA 79, 5370-5373.

Dardenne, M., Pleau, J. M. \& Savino, W. (1982b). Monoclonal antibody against the serum thymic factor (FTS). Immunology Letters 48, 61-64.

Department of Health (1991). Dietary Reference Values for Food Energy and Nutrients for the United Kingdom. Report of the Panel on Dietary Reference Values of the Committee on Medical Aspects of Food Policy. London: H.M. Stationery Office.

Ferguson, E. L., Gibson, R. S., Thompson, L. U. \& Ounpuu, S. (1989). Dietary calcium, phytate and zinc intakes and the calcium, phytate and zinc molar ratios of the diets of a selected group of East African children. American Journal of Clinical Nutrition 50, 1450-1456.

Fraker, P. J., Gershwin, M. E., Good, R. A. \& Prasad, A. S. (1986). Interrelationship between zinc and immune function. Federation Proceedings 45, 1474-1479.

Gatheru, Z., Kinoti, S., Alwar, J. \& Mwita, M. (1988). Serum zinc levels in children with kwashiorkor aged one to three years at Kenyatta National Hospital and the effect of zinc supplementation during recovery. East African Medical Journal 65, 670-679.

Ghavami-Maibodi, S. Z., Collipp, P. J., Castro-Magana, M. C., Stewart, C. \& Chen, Y. (1983). Effect of oral zinc supplements on growth, hormonal levels and zinc in healthy short children. Annals of Nutrition and Metabolism $27,214-219$

Golden, B. E. (1988). Zinc in cell division and tissue growth: physiological aspects. In Zinc in Human Biology, pp. 119-128 [C. F. Mills, editor]. Berlin: Springer-Verlag.

Golden, M. H. N. \& Golden, B. E. (1981). Effect of zinc supplementation on the dietary intake, rate of weight gain, and energy cost of tissue disposition in children recovering from severe malnutrition. American Journal of Clinical Nutrition 34, $900-908$.

Hambidge, K. M. (1988). Mild zinc deficiency in human subjects. In Zinc in Human Biology, pp. $281-296$ [C. F. Mills, editor]. Berlin: Springer-Verlag.

Ho, K.-C. \& Pang, C. P. (1989). Automated analysis of urinary hydroxyproline. Clinica Chimica Acta 185, 191-196.

Kruse-Jarres, J. D. (1989). The significance of zinc for humoral and cellular immunity. Journal of Trace Elements and Electrolytes in Health and Disease $3,1-8$.

Levine, J. B. (1974). Determination in blood with automated analyzers. In Methods of Enzymatic Analysis, $2 \mathrm{nd}$ ed., vol. 2. pp. 856-870 [H. U. Bergmeyer, editor]. New York: Academic Press.

Lunn, P. G., Northrop-Clewes, C. A. \& Downes, R. M. (1991). Recent developments in the nutritional management of diarrhoea. 2. Chronic diarrhoea and malnutrition in The Gambia: studies on intestinal permeability. Transactions of the Royal Society of Tropical Medicine \& Hygiene 85, 8-11.

McClain, C. J., Kasarskis, E. J. \& Allen, J. J. (1985). Functional consequences of zinc deficiency. Progress in Food and Nutrition Science 9, 185-226.

Northrop, C. A., Lunn, P. G. \& Behrens, R. H. (1990). Automated enzymatic assays for the determination of intestinal permeability probes in urine. 1. Lactulose and lactose. Clinica Chimica Acta 187, 79-88.

Prasad, A. S. (1991). Discovery of human zinc deficiency and studies in an experimental human model. American Journal of Clinical Nutrition 53, 403-412.

Prasad, A. S., Meftah, S. \& Abdallah, J. (1988). Serum thymulin in human zinc deficiency. Journal of Clinical Investigation 82, 1202-1210.

Prentice, A., Prentice, A. M., Cole, T. J., Paul, A. A. \& Whitehead, R. G. (1984). Breast-milk antimicrobial factors of rural Gambian mothers. I. Influence of stage of lactation and maternal plane of nutrition. Acta Paediatrica Scandinavica 73, 796-802.

Prentice, A., Stirling, D. M., Sullivan, P. B., Northrop-Clewes, C. A. \& Lunn, P. G. (1991). Raised urinary secretory IgA in chronic diarrhoea. Archives of Disease in Childhood 66, 223-226. 
Rowland, M. G. M., Cole, T. J. \& Whitehead, R. G. (1977). A quantitative study into the role of infection in determining nutritional status in Gambian village children. British Journal of Nutrition 37, 441-450.

Roy, S. K., Behrens, R. H., Haider, R., Akramuzzaman, S. M., Mahalanabis, D., Wahed, M. A. \& Tomkins, A. M. (1992). Impact of zinc supplementation on intestinal permeability in Bangladeshi children with acute diarrhoea and persistent diarrhoea syndrome. Journal of Pediatric Gastroenterology and Nutrition 15, 289-296.

Sachdev, H. P. S., Mittal, N. K., Mittal, S. K. \& Yadav, H. S. (1988). A controlled trial on utility of oral zinc supplementation on acute dehydrating diarrhea in infants. Journal of Pediatric Gastroenterology and Nutrition 7, 877-881.

Shaw, J. C. L., Bury, A. J., Barber, A., Mann, L. \& Taylor, A. (1982). A micromethod for the analysis of zinc in plasma or serum by atomic absorption spectrophotometry using graphite furnace. Clinica Chimica Acta 118 , 229-239.

Simmer, K., Khanum, S., Carlsson, L. \& Thompson, R. P. H. (1988), Nutritional rehabilitation in Bangladesh - the importance of zinc. American Journal of Clinical Nutrition 47, 1036-1040.

Tanner, J. M., Whitehouse, R. H. \& Takaishi, M. (1966). Standards from birth to maturity for height, weight, height velocity and weight velocity: British children, 1965, part II. Archives of Disease in Childhood 41, 613-635.

Walravens, P. A., Hambidge, K. M. \& Koepfer, D. M. (1989). Zinc supplementation in infants with a nutritional pattern of failure to thrive: a double-blind controlled study. Pediatrics 83, 532-538.

Watkinson, M., Aggett, P. J. \& Cole, T. J. (1985). Zinc and acute tropical ulcers in Gambian children and adolescents. American Journal of Clinical Nutrition 41, 43-51.

Weismann, K. \& Hoyer, H. (1985). Serum alkaline phosphatase and serum zinc levels in the diagnosis and exclusion of zinc deficiency in man. American Journal of Clinical Nutrition 41, 1214-1219.

Wheeler, C. R., Salzman, J. A., El-Sayed, N. M., Omaye, S. T. \& Korte D. W. (1990). Automated assays for superoxide dismutase, catalase, glutathione peroxidase and glutathione reductase activity. Analytical Biochemistry 184, 193-199.

Yardrick, M. K., Kenney, M. A. \& Winterfeldt, E. A. (1989). Iron, copper and zinc status: response to supplementation with zinc and iron in adult females. American Journal of Clinical Nutrition 49, 145-150. 